\title{
A critical landscape and urban design analysis of Egypt's new Administrative Capital City
}

\author{
Julian Bolleter \& Robert Cameron
}

To cite this article: Julian Bolleter \& Robert Cameron (2021) A critical landscape and urban design analysis of Egypt's new Administrative Capital City, Journal of Landscape Architecture, 16:1, 8-19, DOI: $10.1080 / 18626033.2021 .1948183$

To link to this article: https://doi.org/10.1080/18626033.2021.1948183 


\section{A critical landscape and urban design analysis of Egypt's new Administrative Capital City}

\section{Abstract}

The Egyptian government has touted the new Administrative Capital City near Cairo as a flagship for 'Smart City' developments across Africa. Despite its association with the UN Sustainable Development Goals, critics argue that the project will be highly detrimental to existing cities, their inhabitants and the natural environment. Using a normative framework derived from the UN goals, this paper examines whether the design of Phase One of the Administrative Capital City (2015-2020) delivers on its grand narratives and commitments. It reveals that the project fails to meet many of its aspirations and is likely to compound Egypt's water supply issues, conflict with fragile desert environments, be vehicular-dependent, isolate everyday Cairenes from Egypt's governance institutions and entrench the power of an autocratic leader. As such, the new capital presents a problematic model of urban development for dealing with Cairo's environmental and societal issues, and for broadly accommodating Africa's rapidly urbanizing population.

Egypt / new cities / African urbanization / sustainable development / United Nations

\section{Introduction}

Forget the numbers. They are not important, and not fixed. We have a dream, and we are building our dreams now.

Khalid al-Husseini, spokesman for the Administrative Capital City ${ }^{1}$

In 2013, a military coup in Egypt led to the ousting of the Muslim Brotherhood and the installation of General Abdel Fattah el-Sisi as president. The following economic crisis saw foreign investment in Egypt plummet dramatically. This was despite growing foreign investment in neighbouring African and Middle Eastern countries from developers seeking to escape the turmoil of the global financial crisis. ${ }^{2}$ Announced on 13 March 2015, the Administrative Capital City is the centrepiece of a wave of new development that Egypt's rulers have used to project an image of a transformed Egypt that is again open for business.

Planners have located the city halfway between Cairo and Suez, some 40 kilometres from Cairo in the Eastern Desert. North American firm, Skidmore, Owings and Merrill, and subsequently a consortium of Egyptian firms (UDC 5+) and global planning and design consultant Dar $^{3}$ have designed the stylized, curvilinear city to be a 700- $\mathrm{km}^{2}$ urban hub, with 32 residential districts to accommodate 6.5 million people (Fig. 1). Moreover, it is intended to include 1,250 mosques and churches, nearly 2,000 schools and colleges, at least six foreign universities, over 600 medical facilities, and 40,000 hotel rooms. It will also have a theme park four times the size of Disneyland, an airport as large as Heathrow and a financial centre with the tallest building in Africa. ${ }^{4}$

The city reflects Sisi's ambition to develop a 'global' or 'world-class' metropolis that symbolizes his 'modern, globalized, capitalist development dreams', , and conforms to the 'Cairo 2050' vision, a plan to effectively create 


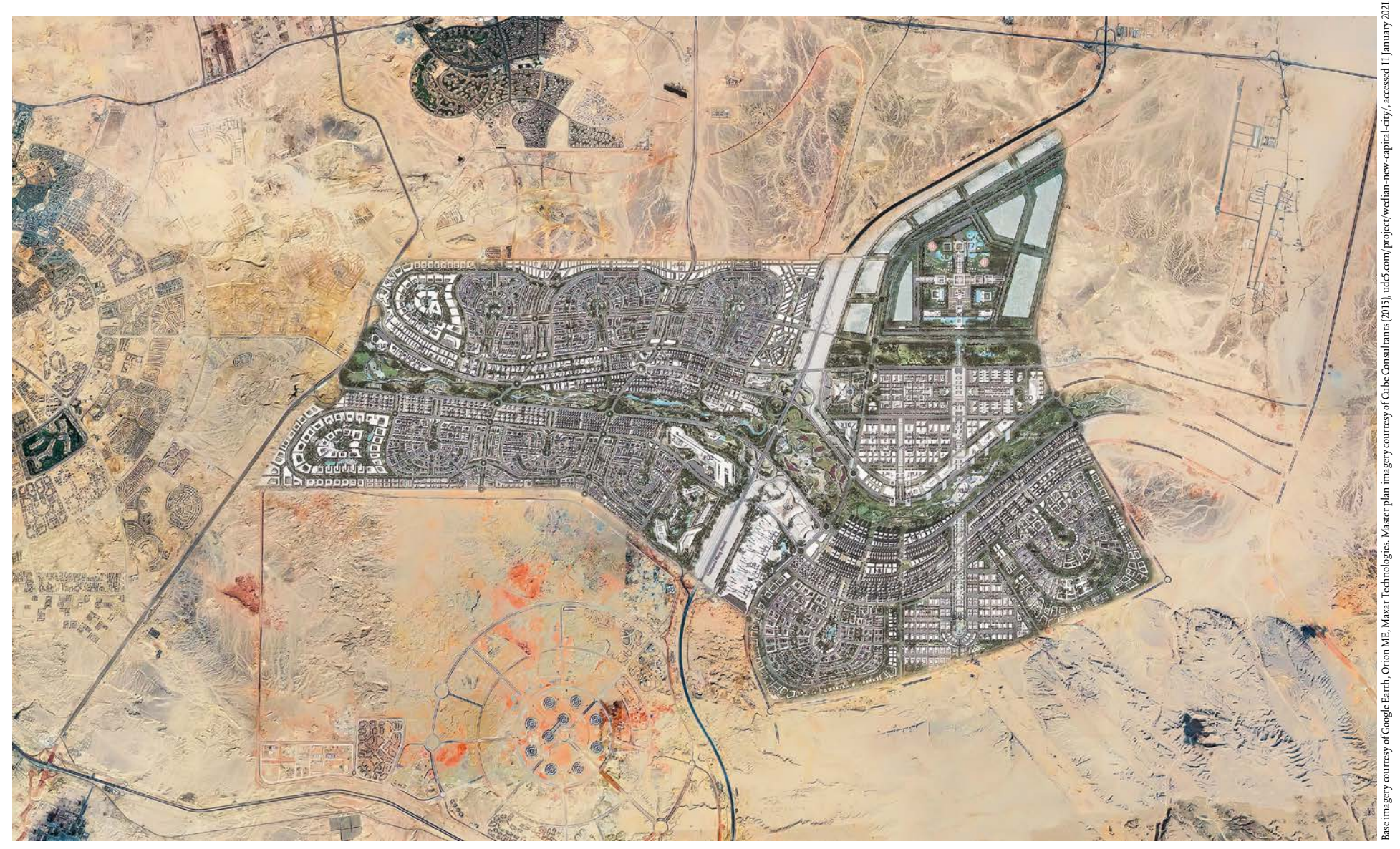

Figure 1 The Phase One master plan projected onto the existing desert site.

'Dubai on the Nile, to attract international investment and tourism'. ${ }^{6}$ The city's proponents claim it will generate jobs for the nation's youth, allowing them to 'pursue their dreams' and be a centre for innovation, alternative energy and sustainable development, state-of-the-art industries, digital solutions and world-class entertainment. ${ }^{7}$

Following on the announcement of the Administrative Capital City, in December 2015 the Egyptian government took part in the Third United Nations Conference on Housing and Sustainable Urban Development (HABITAT III) in Quito (Ecuador). This event was notable because it was the first summit to occur following the adoption of the UN's 2030 Agenda for Sustainable Development and the Sustainable Development Goals. ${ }^{8}$ In the National Report produced for the conference, the Egyptian government states that inefficiencies in the state's ability to utilize human and natural resources present challenges to the achievement of the Sustainable Development Goals. These challenges, they say, could be solved by projects such as the Capital City, which will 'encourage youth to move out of large cities [by] developing the desert and extending out of the Valley and Delta region'. ${ }^{9}$

Against this background, there has been a considerable body of critique of the Capital City project and the urbanization of the Egyptian desert. For example, Egypt-based economist and urban planner David Sims has written in detail about the environmental, social and economic problems associated with Egypt's desert expansion, and has written in an abridged manner about the project in the revised preface of his book Egypt's Desert Dreams: Development or Disaster?..$^{10}$ Journalist and author Rod Sweet has written about the history of the Administrative Capital City in relation to developments in Cairo over the last forty years ${ }^{11}$ and several others have critiqued the social impacts of the neoliberal economic partnerships that have framed the governance of the project. ${ }^{12}$ This paper builds upon these critiques through a detailed (quantitative and qualitative) examination of the landscape and urban design characteristics of the proposed city. As the Egyptian government aspires towards the UN Sustainable Development goals, they have served here to develop a normative framework to assess the Phase One design for the city. ${ }^{13}$ From this analysis, we determine whether it is likely to achieve these goals and, if not, what the social and environmental impacts of such a development might be for Egypt and the broader region.

\section{African urbanization and the legacy of \\ desert development in Egypt}

Currently, more than half of humanity-3.5 billion people-live in cities, and the United Nations project that this number will continue to grow until the urban transition reaches its estimated peak by around $2050(6.7$ billion). ${ }^{14}$ Much of this urbanization will be in Africa, where city populations will effectively triple in the next three decades. By 2050, more than 1.3 billion Africans will live in cities, comprising 21 per cent of the world's urban population. ${ }^{15}$ This presents the significant challenge of creating residential land and infrastructure to house these growing populations. The application of foreign city models to direct African urbanization conforms to a legacy of 'town planning' approaches that were established in the colonial era. In this era, European models for urbanization were imposed on African polities in ways that frequently destroyed pre-existing urban models. ${ }^{16}$ The dominance of imported models for urban development also reflects more recent trends. Specifically, since the early 1990s, which coin- 


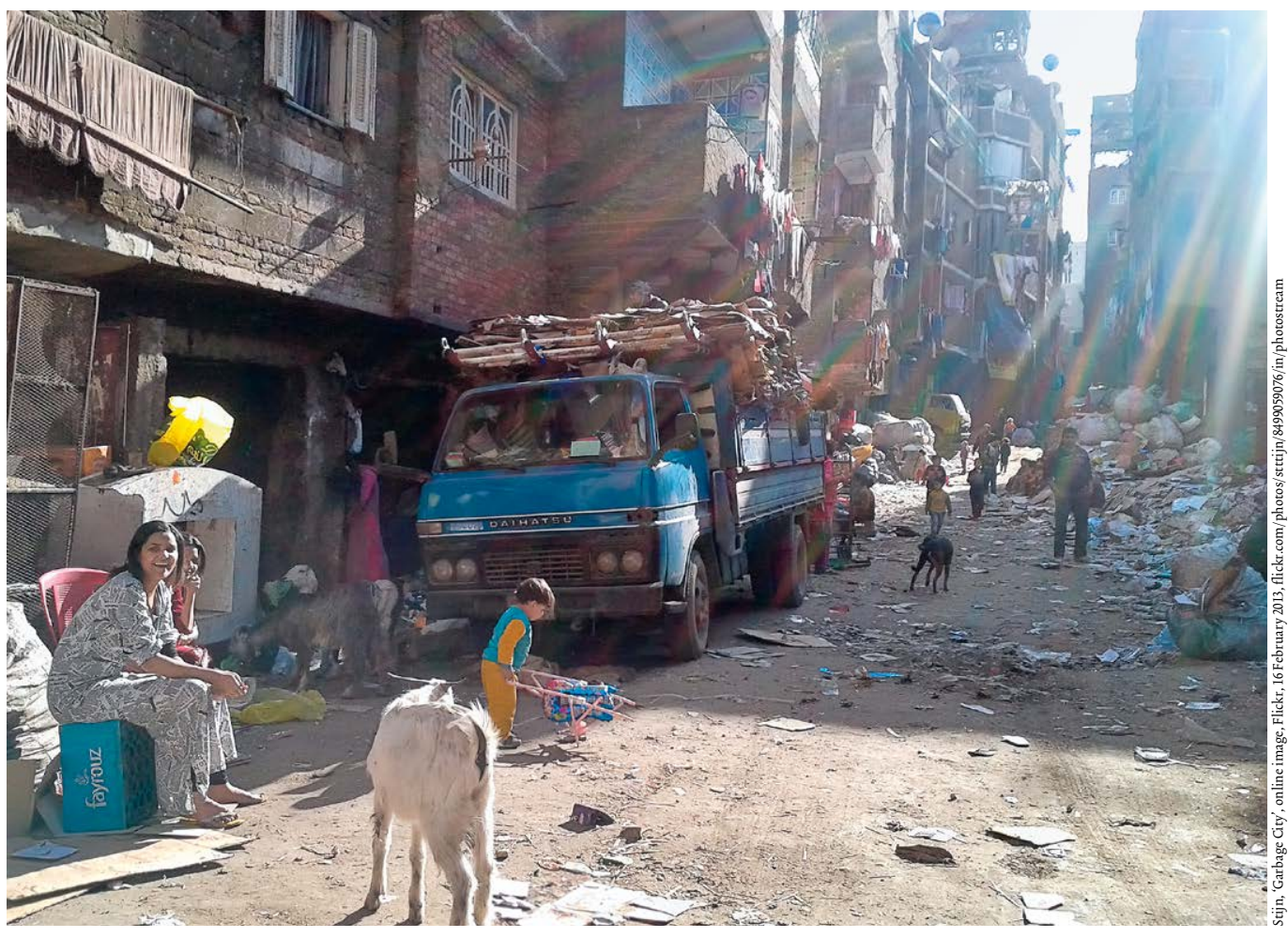

Figure 2 While the Administrative Capital City represents a bid by Sisi to produce a 'world-class, global city', readers should understand the proposal within the (apparently) intractable problems of an informal, crowded Cairo with an increasingly degraded public realm.

cided with the major period of International Monetary Fund-led 'structural-adjustment' programmes, Africa has witnessed general deregulation of its economies and seen rapid economic growth across large parts of the continent. The Administrative Capital City development aligns with this latter category and is a product of the 'opening-up' of Egypt's economy.

Egypt has a long history of urbanizing the desert to the east of Cairo. In the 1970 and 1980 s over a dozen New Town developments were initiated by the state, primarily in the form of subsidized housing to attract the working classes. ${ }^{17}$ In the 1990s, the concept and planning for New Towns was reconfigured to a much more 'neoliberal' mode of politico-economic practice that championed entrepreneurial freedoms, unencumbered markets and private property rights as the best means of improving the well-being of the population. ${ }^{18}$ This was accelerated by Egypt's 1991 agreement with the International Monetary Fund and the World Bank, whose Economic Reform and Structural Adjustment Program can be seen as a larger project of global reform towards the opening of markets for the circulation of international surplus capital. ${ }^{19}$ This push towards economic liberalization has enabled Egypt's elites to recompose the country's desert ecology dramatically. The desert to the east of Cairo is currently being subdivided for about ' 1,300 square kilometres of low-density, car-oriented cityscape and suburbs' ${ }^{20}$ comprising over 500 gated communities. ${ }^{21}$ Despite much effort from successive regimes, these developments have struggled to meet their population projections, as most Egyptians have continued to live in the existing settlements of the fertile Nile Valley and Delta. ${ }^{22}$
The design of the Administrative Capital City

Hoping to distance itself from over half a century of failed New Town developments, the Administrative Capital City represents a bid by Sisi to produce a 'world-class, global city' to attract foreign direct investment and the growing middle classes, and provide an escape from the poverty and disorder of existing cities and towns (Fig. 2). ${ }^{23}$ Egyptian Prime Minister Sherif Ismail has optimistically stated that the new city will 'help reduce Cairo's overcrowding and traffic congestion, which are the kind of problems that would not go away without the government applying non-traditional solutions' ${ }^{24}$ Its proponents also regard it as a partial solution for the lack of public greenspace in Cairo, which (while variable) is typically far below global standards. ${ }^{25}$

The initial vision plan by Skidmore, Owings and Merrill, presented at the 2015 Egypt Economic Development Conference, was produced in partnership with the government of the United Arab Emirates. In 2016, negotiations between the Emirates and the Egyptian government broke down, but the project continued to progress as Sisi had committed to begin construction within three years' time. The governance of the project was then transferred from the Department of Urban Development and Housing to the Egyptian military, who appointed Dar and UDC 5+ as the new urban designers. A result of this transfer of governance and design direction is that many of the aspirational ideas presented at the 2015 conference are not reflected in the design of the current plan. ${ }^{26}$ There is also some confusion in commentary as to what design imagery available online is actually associated with the current proposal. 


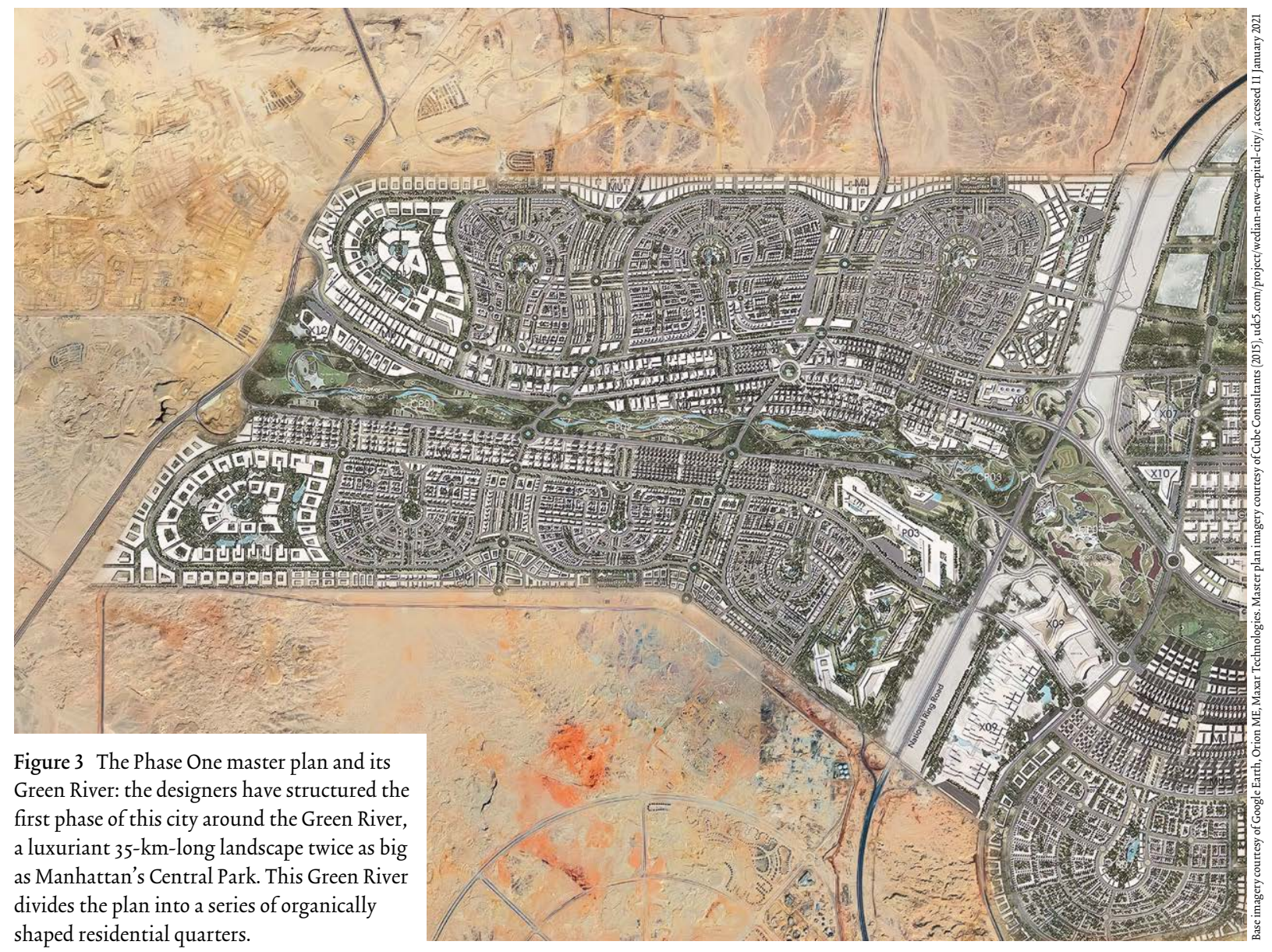

Figure 4 The Presidential Zone comprises a City Beautiful-inspired axial arrangement.

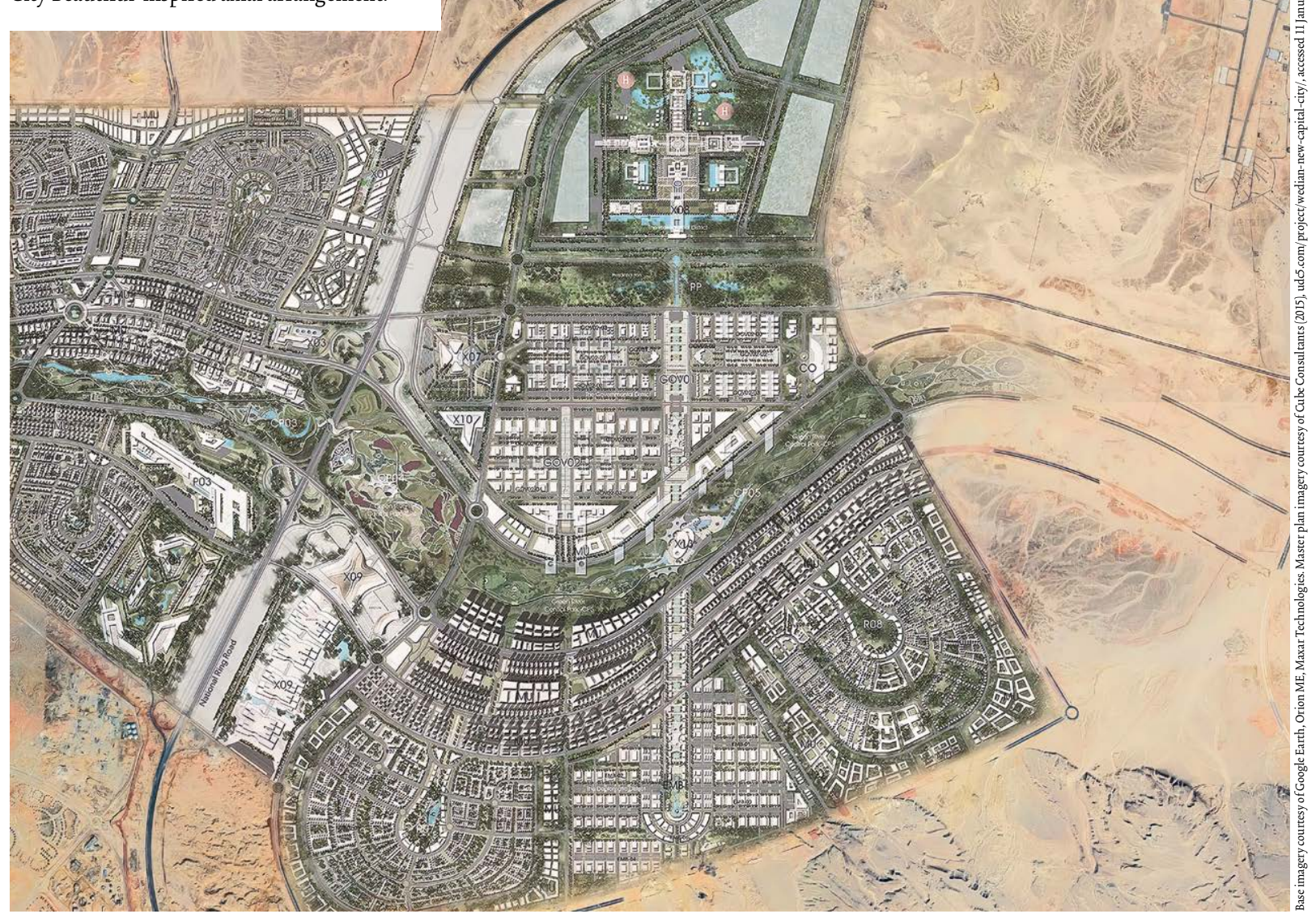




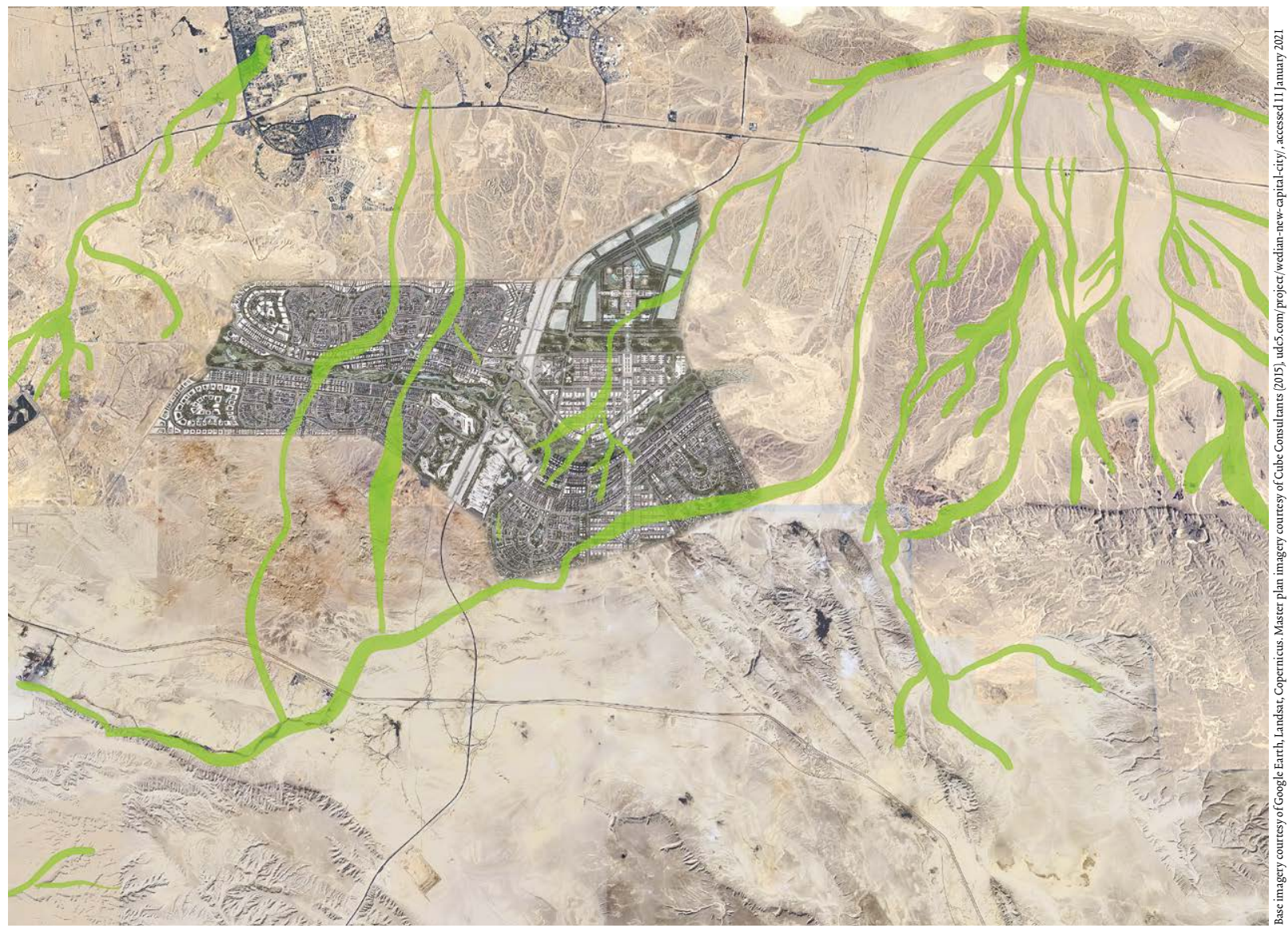

Figure 5 The current Phase One master plan shifts the alignment of the entire city to a predominately east-west axis (defined by the 'Green River') and as such does not respond to the natural wadi topography that generally runs north to south (shown in green).

The master plan for the Administrative Capital City is structured around a park referred to as the Green River (Fig. 3), a lush 35-km-long landscape that includes artificial lakes, a zoo, an aquarium, an arboretum, botanical and sculpture gardens, an outdoor adventure park for mountain biking and rock climbing, pathways for cycling, walking and horseback riding, and waterways for canoeing and sailing. ${ }^{27}$ This Green River divides the plan into a series of organically shaped residential quarters that sit in stark contrast to a highly formal and palatial presidential zone. This new centre of Egyptian government will include 'over thirty ministries, the cabinet, Parliament, a Justice City, a massive conference centre, and the presidency. Next to it will be a diplomatic quarter capable of housing over 110 embassies as well as two exclusive villa areas' (Fig. 4). ${ }^{28}$

\section{A normative framework as review method}

Given the need for urban models that are not socio-ecologically deleterious, to accommodate the accelerated rate of urbanization in Africa and to deal with Cairo's problems precisely, this paper analyses the new city's plan to understand whether it contributes positively to these issues. ${ }^{29}$

To facilitate this analysis, we have created a normative framework that stems from a review of the United Nations Sustainable Development Goals $(\mathrm{SDGs})^{30}$ and the draft Outcome Document of the United Nations Conference on Housing and Sustainable Urban Development (Habitat III). ${ }^{31}$ The SDGs are particularly relevant to an analysis of the Administrative Capital City as Egypt is part of the intergovernmental body that has unanimously endorsed them, having recently secured $\$ 9.8$ billion of international fund- ing through a commitment to achieve them by $2030 .{ }^{32}$ In 2019, Dar also signed a commitment to achieving these goals in its practice. ${ }^{33}$

Increasingly, the UN goals and other international standards (such as those put forward by the International Federation of Landscape Architects) $)^{34}$ are being used to assess the impacts of new urban developments as they provide a standard lens for comparison. ${ }^{35}$ A significant criticism of this approach, however, is that as a non-binding set of goals, these frameworks are mostly qualitative and in many cases vague, which leaves much room for interpretation. ${ }^{36}$ Rather than a problem, the application of these frameworks in design assessment is an opportunity to critique their efficacy in the face of larger economic and political forces. To provide a cohesive normative framework, we have grouped the goals into two broad categories of environmental and societal aspirations.

Environmental goals advocated by the UN are for cities and urban centres that protect, conserve and restore their ecosystems, water, natural habitats and biodiversity, minimize their environmental impact and embody sustainable consumption and production patterns-goals that all relate to UN SDG target 11.6: 'reduced environmental impact of cities' ${ }^{37}$ These goals are proposed to be achieved by integrating ecosystem and biodiversity values into national and local planning and development processes. ${ }^{38}$

The societal goals the UN advocates for are 'cities and human settlements that promote inclusivity and ensure that all inhabitants, without discrimination of any kind, can inhabit just, safe, healthy, accessible, affordable, resilient and sustainable urban areas to foster prosperity and quality of life for all'. ${ }^{39}$ Furthermore, such areas are to promote civic engagement, engender 


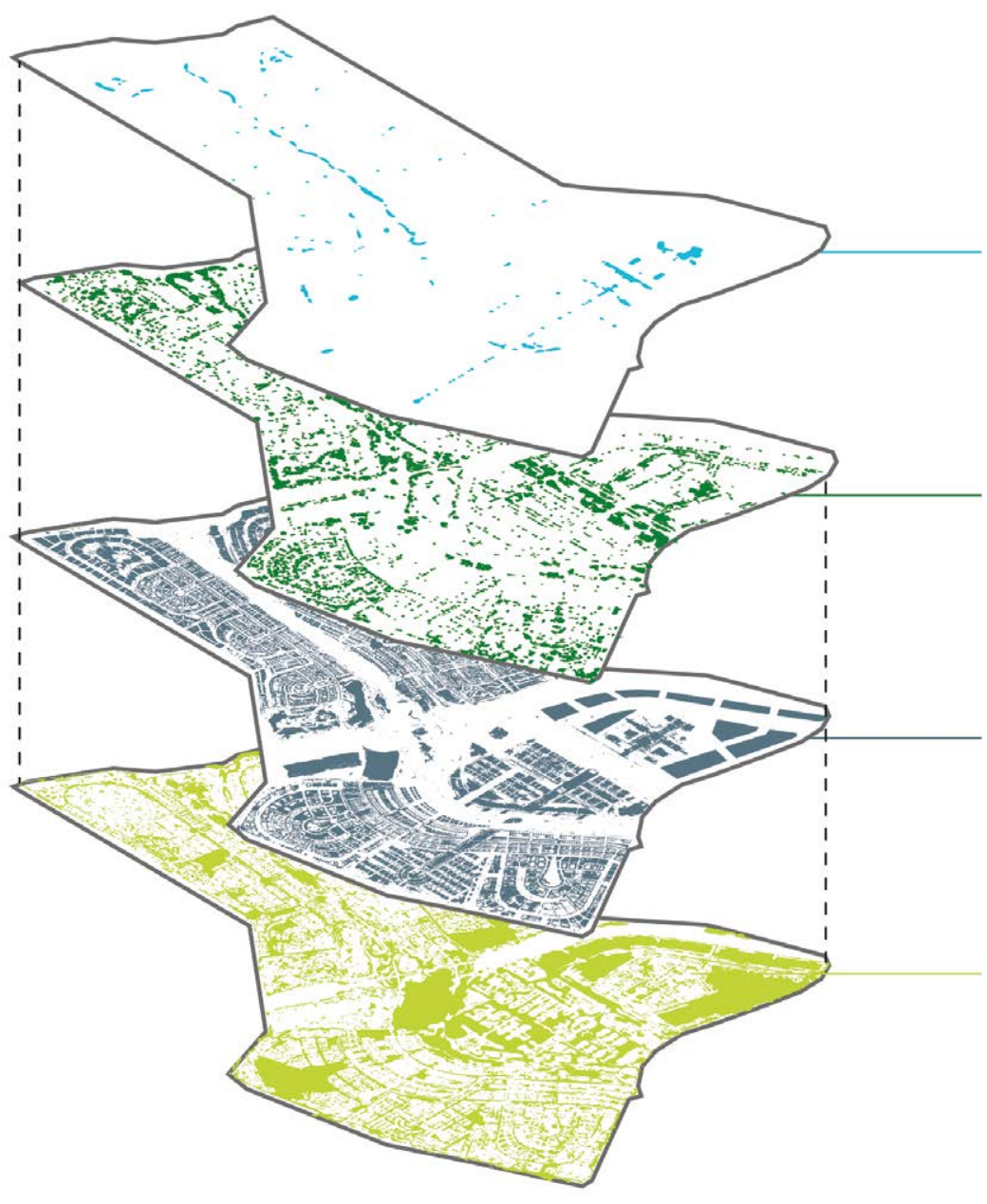

Water $-3 \% \mid 2.5 \mathrm{~km}^{2}$

Canopy $-4 \% / 7 \mathrm{~km}^{2}$

Built Space $-52 \% \mid 90.5 \mathrm{~km}^{2}$

Green Space - $41 \% \mid 70 \mathrm{~km}^{2}$

Figure 6 Phase One plan spatial analysis. Exploded isometric view showing the breakdown of areas in the master plan. An enormous $41 \%$ of the area of the development (70,000 hectares) is to be greenspace. These figures are indicative only.

a sense of belonging and ownership among all their inhabitants. They are also to prioritize safe, inclusive, accessible, green and quality public spaces that are family-friendly, enhance social and intergenerational interactions, cultural expressions and political participation, and foster social cohesion, inclusion and safety in peaceful and pluralistic settings, where the needs of all inhabitants are met. ${ }^{40}$ These aspirations relate to UN SDG targets 11.3: 'inclusive urbanization and participatory, integrated planning', 11.7: 'universal access to safe, inclusive and accessible green spaces' and 11.2: 'universal access to safe, affordable, accessible and sustainable transport systems. ${ }^{21}$

The following sections set out the degree to which these lofty societal and environmental goals are evident in the planning for the Administrative Capital City.

\section{Egypt's new capital and environmental aspirations:} Water consumption and ecological destruction

In response to the UN SDGs, the initial Skidmore, Owings and Merrill proposal made much of being in tune with nature and ecology by fitting into the 'natural wadi topography' of the desert. ${ }^{42}$ By aligning with existing flows of underground water and nutrients, these resources could be 'tapped into and advanced to create green corridors by supplementing and enhancing them with things like recycled waste water' ${ }^{43}$ The Green River of the current proposal shifts the alignment of the entire city to an east-west axis that is unlikely to have access to these potential water sources. While the original design ostensibly integrates itself with the desert landscape, this approach becomes entirely symbolic in the current proposal (Fig. 5). ${ }^{44}$ The terraforming of the desert poses critical issues for Egypt's desert ecology, which accounts for 87 per cent of its biodiversity ${ }^{45}$ and has the potential to impact a majority of vulnerable or endangered species. ${ }^{46}$ Without proper design consideration it may also lead to a loss of human life, as evidenced in the case of New Cairo, which has been unable to cope with severe flooding, resulting in a protracted urban crisis. ${ }^{47}$

The new Capital City has a sprawling urban footprint that produces large swathes of green landscape and subsequently has significant implications for water usage. The design does not employ urban form to protect these landscaped areas from the loss of moisture from evapotranspirationan urban and landscape design practice that is fundamental to the provision of green landscape in traditional Arabic Islamic urbanism. Rather, residential buildings float in a lush resort-like green landscape. A quantitative analysis of the master plan indicates that an enormous 41 per cent of the area of the development (7,000 hectares) is to be green space (Fig. 6). ${ }^{48}$ Within a detailed area of the city plan, 26 per cent appears to be grass, an ecologically sterile, imported plant material with excessive irrigation requirements and minimal ecological value.

This vast reserve of greenspace-much larger than in the first proposalwill require significant amounts of water, energy (to move the water) and chemicals to survive Cairo's hot and arid climate. In a bid to provide this required virtual river of freshwater, the project's planners say two pipelines will connect the new capital with the Nile River, each with pumping stations with a capacity of $125,000 \mathrm{~m}^{3}$ per day. Eventually, a third line will provide water from the Red Sea, presumably desalinated. ${ }^{49}$ 


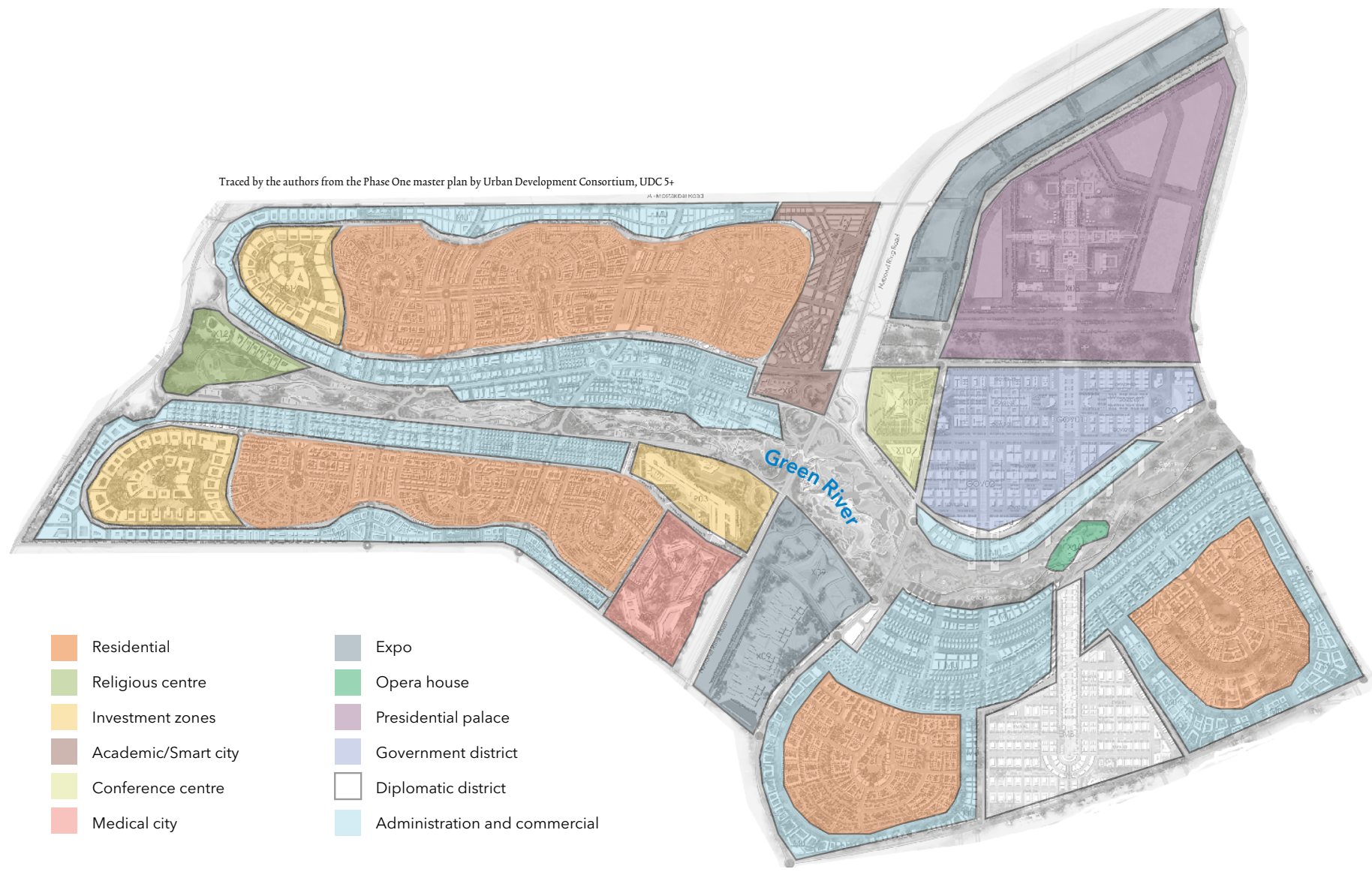

Figure 7 The typically monofunctional zoning of the Phase One Administrative Capital City plan.

Even with the intention to use treated sewage effluent for a proportion of the greenspace irrigation, this water could provide much more significant benefits if directed towards the irrigation of agricultural land to bolster food security, or greenspace irrigation in Cairo, where the bulk of Egypt's population resides. ${ }^{50}$ Under the current proposal, all the water consumed for irrigation in the new city will be lost, since the desert location is far from the Nile Valley and as such seepage from irrigation water will not recharge the Nile Valley aquifers. ${ }^{51}$

While the over-extraction of water from the Nile, expensive desalination and conveyance of water all have significant environmental implications, such a profligate use of water also raises equity issues given the water shortages experienced by residents of older Cairo quarters. ${ }^{52} \mathrm{~A}$ recent report by 10 Tooba, an organization of architecture and engineering professionals, found that 'up to a third of households in Cairo are deprived of necessities such as safe water and sanitation ${ }^{153}$ - not to mention that many villages in rural Egypt are already suffering drought in their farms. ${ }^{54}$

In this water-stressed context, the extensive irrigation required to sustain the new Capital City's thirsty landscape could actually make conditions worse for residents of older Cairo quarters and as such could constitute a 'social crime'.55 Indeed, comparatively recent surveys have shown that the quality of life has declined in Cairo and in other Egyptian cities. Some of the reasons are water shortages, the decline of urban areas, and the limited amount of public greenspace. ${ }^{56}$ This worrying trend is symp- tomatic of a broader situation. The IPCC predicted that 75 to 250 million Africans would be exposed to stressed water sources by the 2020s, and 350 to 600 million will be vulnerable by the 2050s. ${ }^{57}$

Concerning its substantial irrigation requirements and ecological destruction, the new city appears to stray far from the normative framework's aspiration for developments to 'minimize their environmental impact, and embody sustainable consumption patterns' ${ }^{58}$

\section{Egypt's new capital and societal aspirations:}

Inclusivity and equity

Despite the Egyptian government's commitments to the UN SDGs, the design of the Administrative Capital City is problematic from the perspective of societal inclusivity and equity. Here, we set out signs of the new city's potential to result in sociospatial segregation for housing, public transport, social mobility and democracy.

In the last decade, land prices in the Greater Cairo region increased sixteen-fold, making new developments affordable for upper-middle-income Egyptians only. ${ }^{59}$ In the new city there are multiple indications that almost all of its housing will be created by private developers, aiming for the types of middle- and high-end compounds that already characterize New Cairo and other satellite cities around Cairo. ${ }^{60}$ In a new development typical of the Capital City's residential districts, the smallest apartments for sale were two-bedroom $123-\mathrm{m}^{2} \mathrm{~d}$ wellings, and the most significant were 


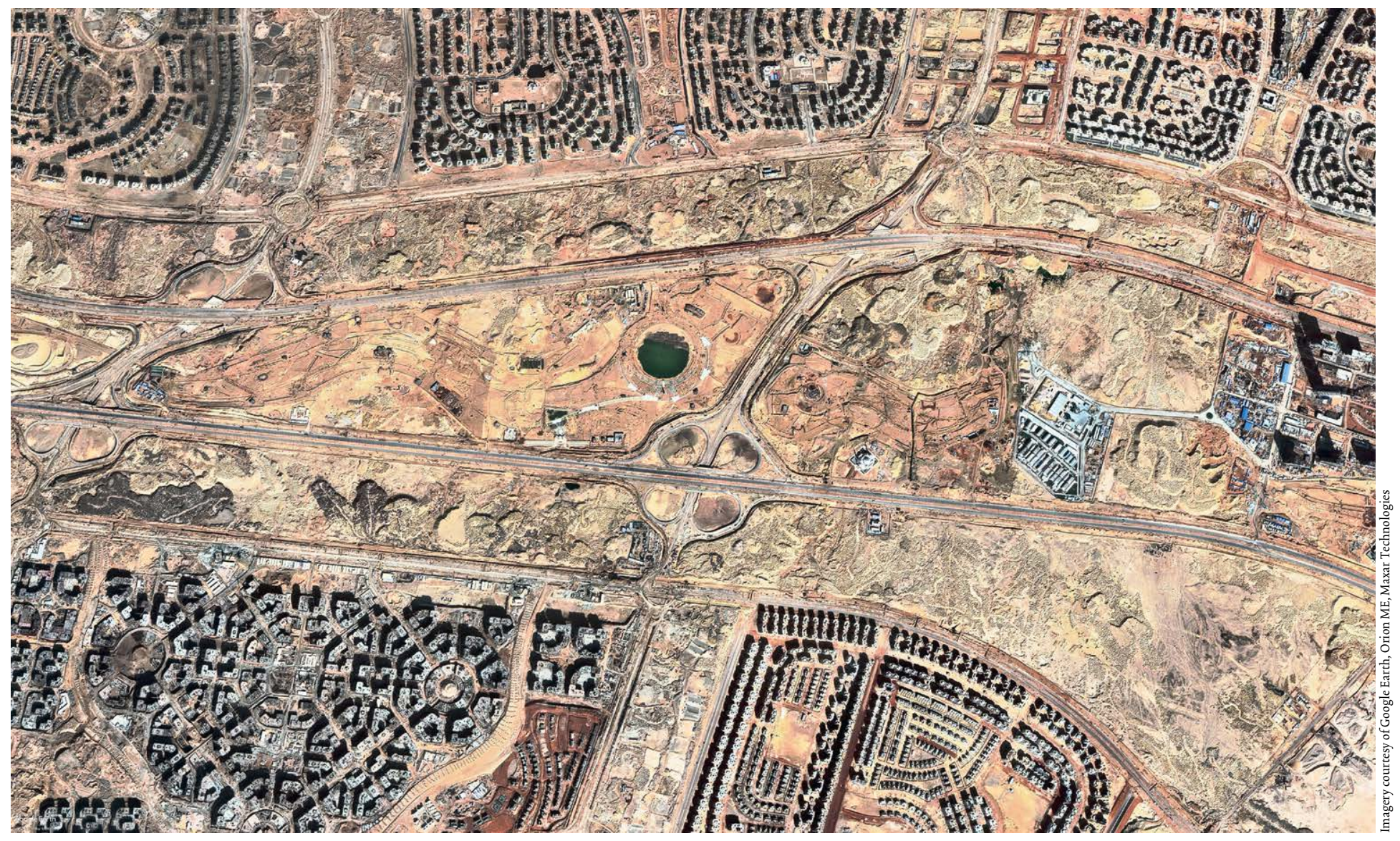

Figure 8 Vehicular dominance: Aerial photos of the Green River reveal the vehicular dominance characterizing the Administrative Capital City, with major freeways separating the park from the surrounding urban areas.

$222 \mathrm{~m}^{2} .{ }^{61}$ Given their substantial size, these dwellings will not be cheap to construct and those in the expansive residential villa zones will inevitably be even more expensive.

The monofunctional zoning of the plan contrasts with the complexity of Cairene streetscapes and the kinds of informal retail markets that account for at least 45 per cent of jobs in Egypt (Fig. 7). ${ }^{62} \mathrm{~A}$ lack of affordable housing and jobs generated by the informal economy will mean that poorer Cairenes could experience the new city's exclusive communities only in a service capacity. This population will contrast with the group of professional expatriates who live a life of comparative ease and affluence, and who will travel unobstructed-principally in private vehicles-through a 'safe, quiet and smooth place'. ${ }^{33}$ Aerial photos of the construction of the Green River confirm the vehicular dominance characterizing the city, with a major freeway separating the park from the surrounding urban areas (Fig. 8).

Problems of housing affordability will be compounded by a lack of public transport. Although none of the available plans of the new capital indicate land reserves for rail transport lines, several government officials have made statements that planning for a rapid-rail passenger link from Madinat al-Salam to the new capital 'is well advanced'. ${ }^{64}$ The problem is that to recover the massive investment plus operating costs, any private operator will need to charge fares that will be unaffordable to the majority of potential commuters, and those who can pay will probably prefer their private cars. ${ }^{65}$

Even if developers could deliver convenient, fast and affordable public transit to and from the city, transit within the city will remain problem- atic. The monofunctional zoning and sprawl of the plan means that freedom of mobility will be predicated on having access to a car and therefore will be denied to most Cairenes working (or living) in the new city.

Government and developers have promoted the city as a new and more inclusive public sphere in which a young, industrial pioneering class will achieve social mobility through hard work and entrepreneurship 'no matter their class, race, gender or sexuality ${ }^{66}$ Eric Denis, director of Géographie-cités lab at the Université Paris 1 Panthéon-Sorbonne argues that in this narrative of urban renaissance or nahda umraniya the old city and its inhabitants are recast as risky, hazardous and unconducive to a model society. ${ }^{67}$ This, he argues, has allowed 'buyers and promoters to divert attention from the private and above all very exclusive appropriation of public lands, and therefore from the disappearance of space and resources around the capital'. ${ }^{68}$ The relative cruelty of this approach is also illustrated by the many people in Cairo who have been driven into massive debt as they have tried to compete in an entrepreneurial scene dominated by the privileged. ${ }^{69}$ The segregation and fortification of developments such as the new city will further exacerbate these issues and reduce the possibility of meaningful social interaction, public debate and upward social mobility. ${ }^{70}$

While the landscape and urban design of the new city will actively work against societal inclusivity on a day-to-day basis, it also will act to legitimize and consolidate the rule of Egypt's autocratic leader. Since the 2011 uprising, Sisi has progressively moved to produce a new and more extreme strain of authoritarianism that surpasses that of the country's previous rulers. ${ }^{71}$ Reflecting this, recent instances of disappearance and torture have 


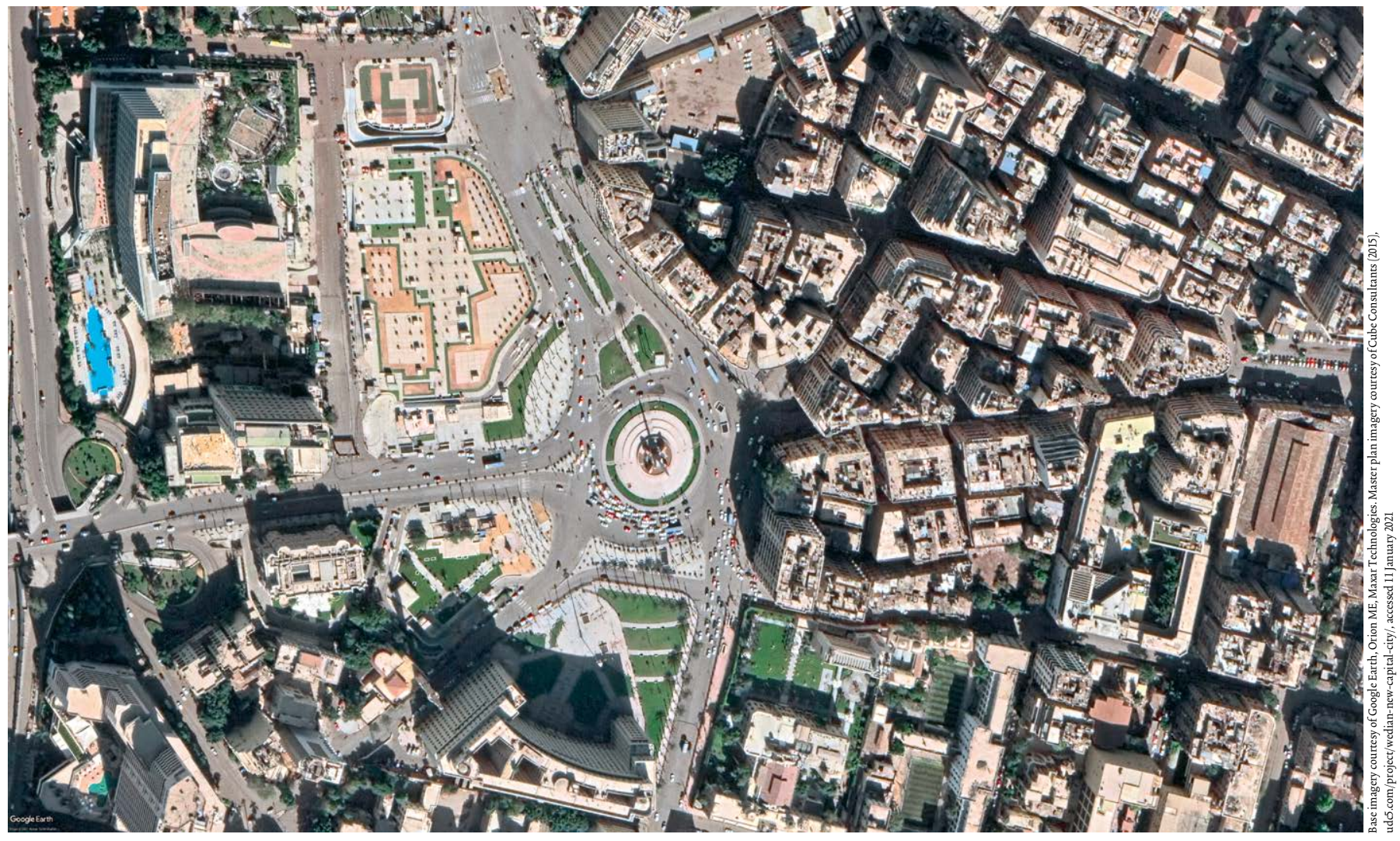

Figure 9 Since its establishment, the control of Tahrir Square -a significant public space close to the Egyptian parliamenthas seemed central to controlling the country.

spiked, and Egypt currently has more than 40,00o political prisoners. ${ }^{72}$ In the old city, the application of this power has traditionally been offset by a dense and compact social order where proximity between classes has enabled community interests to humanize links with the government and obtain political space otherwise denied to them. ${ }^{73}$ Indeed, since its establishment in 1860, the control of Tahrir Square-a significant public space close to the Egyptian parliament-has seemed central to controlling the country (Fig. 9). Tahrir (liberation) Square was of central importance to demonstrators in the urban wars that took place between 2011 and 2013 due both to its symbolic role as the "home of the civic spirit of Egypt ${ }^{7}{ }^{74}$ but also because of its urban form that is difficult to police. ${ }^{75}$ While plans to develop the eastern desert were underway before the Sisi regime, the decision to move as far as possible from the centre to the eastern desert was likely in part an attempt to construct an urban counterimage to Tahrir and the Belle Époque urban centre. An image that rejects the cultural significance of the old city because in many ways, it is a symbol of hope and identity for the most marginalized in Egyptian society.

By moving governance away from the old city whose urban form has been conducive to protest and rebellion in the past, the Administrative Capital City represents an attempt to protect those in power from a repeat of the unrest of the Arab Spring. ${ }^{76}$ The regime explains the rationale for this move as providing security against terrorist acts, better protecting government buildings and government officials and providing maximum security for foreign missions and their staff." Readers can interpret this security rationale to ensure those core government institutions are isolated from the masses and any political expressions based upon them. ${ }^{78}$
'World-class' city models and luxuriant landscapes

Besides the points listed previously, there are several other elements of the design that could be interpreted as presenting an imaginary that reinforces the autocratic tendencies of the master plan. First, master plans, in their graphical forms, reveal the prevailing ideologies of the regimes they sustain. ${ }^{79}$ For example, the Administrative Capital City has adopted a grand, ordered and axial arrangement for the government buildings found in other 'world-class' capital cities such as Canberra, Washington, DC, and New Delhi (Fig. 10), ${ }^{80}$ while the buildings appear to draw on the architectural aesthetics of Baron Haussmann's nineteenth-century Paris or New York's Art Deco architecture of the early twentieth century, evoking historical continuity, wealth and permanence and reflecting a desire for social order and control. ${ }^{81}$

There is also evidence to suggest that the Administrative Capital City's cornucopia of greenspace works to legitimize the current regime. These kinds of luxuriant landscapes are-in arid and Islamic settings-often a symbolic recreation of the Islamic Paradise. ${ }^{82}$ Garden designer John Brookes explains that the potency of the image of Paradise in Islamic culture is that descriptions of the Garden of Paradise are held up as something to not only seek for in the afterlife, but also to reconstruct in this world. ${ }^{83}$ The deployment of greenspace is instrumental in the preservation of autocratic power since the action of greening the desert, and by extension urban development, effectively has God's imprimatur.

Through his ability to defeat the desert, the president can display his strong and effective leadership and-to some degree-his concern for everyday Egyptians. ${ }^{84}$ While globally 'power is infused in the ownership of space, the resources to transform it, the process of shaping it' ${ }^{85}$ this situation is 


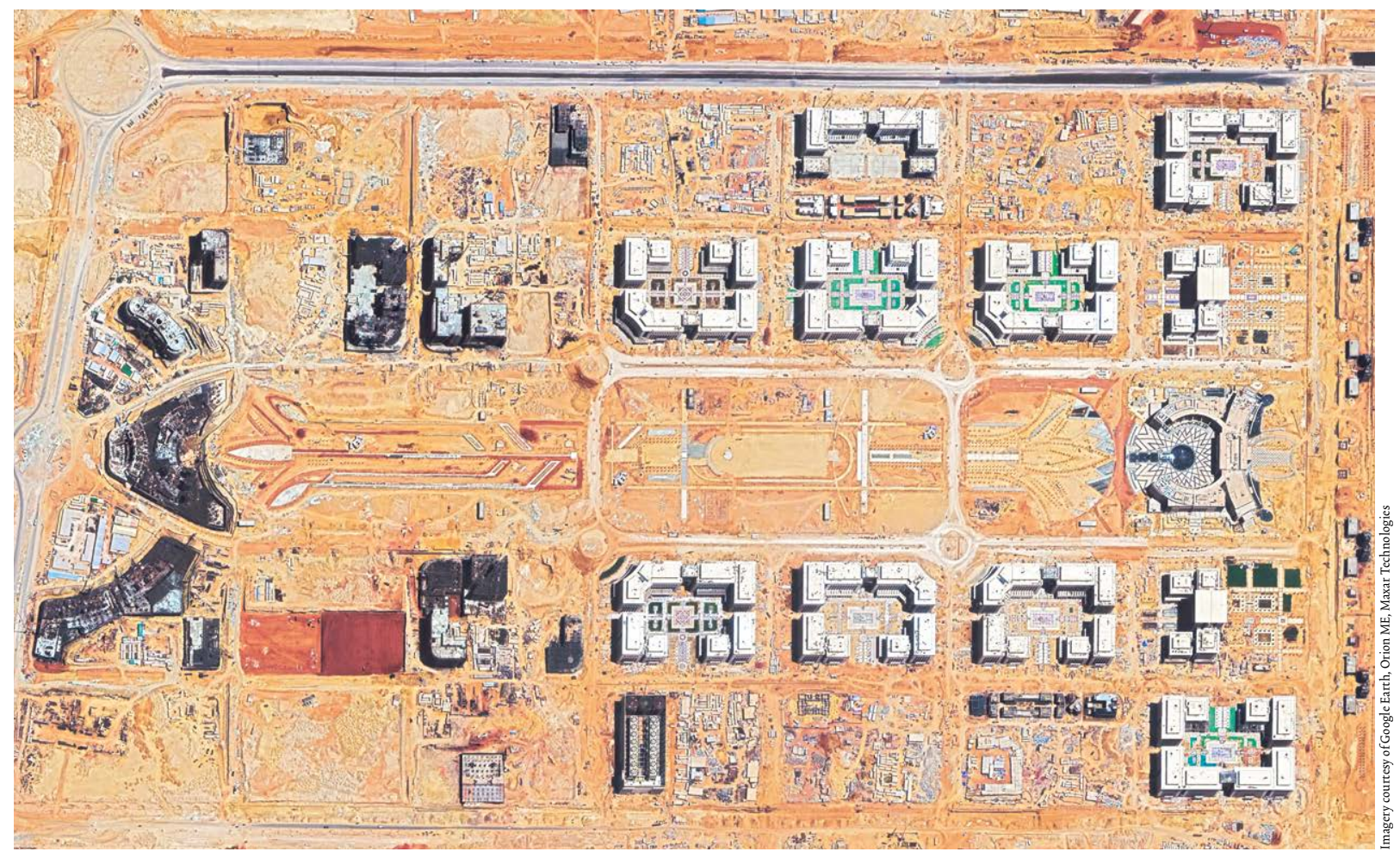

Figure 10 The axial formality of the Presidential Zone.

particularly important in Egypt because of the dryness of the desert landscape and the religious symbolic underpinnings of luxuriant greenery. ${ }^{86}$ In this way, the presence of luxuriant greenspace becomes a barometer for the wealth and power of those commissioning the project. ${ }^{87}$

As attested to above, given the foreseen lacuna of affordable housing, public transport and informal economy jobs, and the isolation of governance functions, the new Administrative Capital City clearly will struggle to deliver the normative framework's aspirations for inclusivity, civic engagement, sense of belonging for all and social cohesion. ${ }^{88}$

\section{Conclusions}

In this paper, we have used the environmental and societal aspirations of the UN as a normative framework. Assessment of the plan of the Administrative Capital City against this framework demonstrates that the designs are unlikely to achieve these environmental and societal goals, despite rhetoric from the government and designers that appears to align with them. Much like its predecessors, and given its similar landscape and urban design, the new city is likely to be a massive consumer of freshwater, precipitate the destruction of broad swathes of the desert environment, and exclude Cairenes who cannot afford a private car or expensive housing. However, unlike past new city developments in Egypt this plan represents a Pharaonic desire for displaying and consolidating the power of an autocratic ruler.

That there is such a disconnect between the rhetoric and reality of this and other contemporary new city developments points in some ways to the inadequacy of frameworks such as the UN SDGs for steering global urbanization. This can be attributed to the vague definition of targets used in these frameworks and the non-binding nature of these agreements, which leaves many development outcomes open to interpretation. This situation has allowed much of urban development in Africa and other parts of the developing world to continue its trajectory of dismantling and restructuring existing urban order for the benefit of an elite ruling class under the guise of social, environmental and economic responsibility.

A shared set of values and targets such as those set out in the UN SDGs is potentially instrumental in the context of African urbanization in the coming decades. However, unless these goals are clear and enforceable, they run the risk of obfuscating rather than attenuating the race towards ecological and social collapse. Here, designers and design institutions (beyond those commissioned to design these projects) have an opportunity and responsibility to help to better define, embed and promote the outcomes of these frameworks in relation to urban development and to identify where they are being used to obfuscate destructive practices. 
NOTES

1 Quoted in Ruth Michaelson, “'Cairo Has Started to Become Ugly": Why Egypt Is Building a New Capital City', The Guardian, 8 May 2018, theguardian.com/cities/2018/may/08/cairowhy-egypt-build-new-capital-city-desert.

2 Khaled Adham and Mostafa Hossam, 'The Gulfanization of Egypt', Al Manakh-Gulf Cont'd 2/23 (2010), 468-471: 470.

3 Skidmore, Owings and Merril produced the original strategic master plan for the ACC. Dar was commissioned to 'assess and validate the Strategic Master Plan for the whole area as well as the Master Plan for Phase 1 (16,80o ha) and the Detailed Master Plan for the Phase 1 Priority Area (4,140 ha)', which was produced by a consortium of Egyptian development firms called UDC 5+. DAR, 'New Administrative Capital', dar.com/ work/project/new-administrative-capital, accessed 7 January 2021; UDC 5+, 'Cairo New Administrative Capital Wedian', udc5.com/project/wedian-new-capital-city/, accessed 7 January 2021.

4 Mohamed Mohsen, 'Egypt's New Administrative Capital Set to Build “Large' Airport"', egyptianstreets.com/2018/08/05/ egypts-new-administrative-capital-will-be-getting-a-newairport/, accessed 7 January 2021.

5 Harry Pettit, 'Hopeful City: Meritocracy and Affect in Global Cairo', International Journal of Urban and Regional Research 42/6 (2018), 1048-1063: 1049; Saskia Sassen, 'The Global City', in: David Nugen and Joan Vincent (eds.), A Companion to the Anthropology of Politics (Oxford: Blackwell Publishing Ltd, 2007) 168-179.

6 Pettit, 'Hopeful City', op. cit. (note 5), 1048.

7 David Sims, Egypt's Desert Dreams: Development or Disaster? (Oxford: Oxford University Press, 2015), xxxvii.

8 UN-Habitat, About Habitat III (2015), habitat3.org/theconference/about-habitat-3/, accessed 7 January 2021.

9 Arab Republic of Egypt, Arab Republic of Egypt National Report: Third United Nations Conference on Housing and Sustainable Urban Development (HABITAT III) (2016).

10 Sims, Egypt's Desert Dreams, op. cit. (note 7), xxiii-lxxii.

11 Rod Sweet, 'Dreamland: A Critical Assessment of Egypt's Plan for a Brand New Capital', Construction Research and Innovation 10/1 (2019), 1-9.

12 Hassan Elmouelhi, 'New Administrative Capital in Cairo: Power, Urban Development and Social Injustice: The Official Egyptian Model of Neoliberalism', in: Ala Al-Hamarneh, Jonas Margraff and Nadine Scharfenort (eds.), Neoliberale Urbanisierung: Stadtentwicklungsprozesse in der arabischen Welt (Bielefeld: Transcript, 2019), 215-254; Ursula Lindsey, 'The Anti-Cairo', Places Journal (March 2017); Patrick Loewert and Christian Steiner, 'The New Administrative Capital in Egypt: The Political Economy of the Production of Urban Spaces in Cairo', Middle East-Topics $\mathcal{E}$ Arguments 12/1 (2019), 66-75.

13 Detailed information about the scope of the entire project has not been disclosed by the Egyptian government. However, according to Major General Ahmed Zaki Abdeen, chairman of the New Administrative Capital, in September 2020 Phase One of the project was mostly complete, work had begun on Phase Two (an area of 47,000 feddans ( 48,778 acres)) and Phase Three (90,00o feddans (93,405 acres)). Mohammed Abu Zaid, 'Egypt's New Administrative Capital Will Be Center of Middle East, Says Official', arabnews.com/node/1730476/middle-east, accessed 11 January 2021.
14 United Nations, World Urbanization Prospects: The 2018 Revision (2018), xix, population.un.org/wup/Publications/ Files/WUP2018-Report.pdf.

15 Femke van Noorloos and Marjan Kloosterboer, 'Africa's New Cities: The Contested Future of Urbanisation', Urban Studies 55/6 (2018), 1223-1241: 1224.

16 Nicholas Knebel, 'In Search of a Model for the African Metropolis: Observations and Contributions over Ten Years of Practice, Teaching and Research in Ethiopia', mygutech. gutech.edu.om/wordpress/wp-content/uploads/2016/10/ KNEBEL-N_2012_African-Perspectives_In-Search-of-a-Modelfor-the-African-Metropolis.pdf, accessed 3 February 2021.

17 Hegazy and Moustafa provided a detailed history of the development of new cities in the eastern desert and discuss the reasons why most of these projects have failed to achieve their population goals. Ibrahim Rizk Hegazy and Wael Seddik Moustafa, 'Toward Revitalization of New Towns in Egypt Case Study: Sixth of October', International Journal of Sustainable Built Environment 2/1 (2013), 10-18: 11-12.

18 David Harvey, 'Neoliberalism as Creative Destruction', Geografiska Annaler: Series B, Human Geography 88/2 (2006), 145-158: 145 .

19 David Harvey, 'Neoliberalism and the City', Studies in Social Justice 1/1 (2007), 2-13: 10.

20 Sims, Egypt's Desert Dreams, op. cit. (note 7), xxix.

21 Nesma Mohamed Salah and Hany M. Ayad, 'Why People Choose Gated Communities: A Case Study of Alexandria Metropolitan Area', Alexandria Engineering Journal 57/4 (2018), 2743-2753: 2744 .

22 World Bank, Egypt: Urban Sector Update, vol. 1. WorldBank, Middle East and North Africa Region, Cairo (2008).

23 Oren Ahoobim, Laura Goldman and Shanti Mahajan, 'What Makes a World Class City?', ssir.org/articles/entry/ what_makes_a_world_class_city, accessed 11 Jan 2021; Benson Mutuku, Luc Boerboom and Ana Mafalda Madureira, 'The Role of Planning Support Systems in National Policy Transfer and Policy Translation in Secondary Cities', International Planning Studies 24/3-4 (2019), 293-307: 293.

24 Sims, Egypt's Desert Dreams, op. cit. (note 7), xxxvii.

25 By way of example, the share of public greenspace in the old city quarters is less than $0.1 \mathrm{~m}^{2}$ per capita in many casesmuch less than the standard of $28 \mathrm{~m}^{2}$ per capita that tends to be the standard in Western cities. Mohamad Abotera and Safa Ashoub, 'Billboard Space in Egypt: Reproducing Nature and Dominating Spaces of Representation', Urban Transcripts 1/3 (2017); Julian Bolleter, Scavenging the Suburbs: Auditing Perth for 1 Million Infill Dwellings (Perth: University of Western Australia Publishing, 2015).

26 Daniel Ringelstein, interviewed by Julian Bolleter and Robert Cameron, June 2020.

27 The Green River is being designed by Archplan Architects \& Planners, Cube Consultants, Land Consultants, Ökoplan Engineering Consultations, and Yasser Mansour Concept Architects. Asmaa Kamaly, 'The Construction of the $35-\mathrm{Km}$ Green River in the Egyptian New Administrative Capital', Egypt Architecture News, 17 June 2019, worldarchitecture.org/ article-links/eccvp/the-construction-of-the-35-km-greenriver-in-the-egyptian-new-administrative-capital.html, accessed 7 January 2021.
29 Developers have not yet delivered enough of the plan to assess the actual development itself. However, in time this will be a worthy research project for future researchers.

30 United Nations, The Sustainable Development Goals Report 2017, unstats.un.org/sdgs/files/report/2017/thesustainabledevelopmentgoalsreport2017.pdf, accessed 7 January, 2021.

31 United Nations General Assembly, Draft Outcome Document of the United Nations Conference on Housing and Sustainable Urban Development (Habitat III) (2016), digitallibrary.un.org/ record/1290312?ln=en\#record-files-collapse-header, accessed 7 January, 2021.

32 Doaa A. Moneim, 'Egypt Secured $\$ 9.8$ bln for SDGs 2030 Finance in 2020; $\$ 6.7$ for Sovereign Projects', english.ahram. org.eg/NewsContent/3/12/397390/Business/Economy/ Egypt-secured--bln-for-SDGs--finance-in-;--for-sov.aspx, accessed 14 January 2021.

33 DarMagazine i17 (July 2019), 6-11, dar.com/content/ publications/117/, accessed 14 January 2021.

34 International Federation of Landscape Architects Asia Pacific, IFLA Asia-Pacific Region Landscape Charter (2015), iflaapr. org/sites/default/files/content-files/IFLA-APR-CharterFinal.pdf, accessed 7 January 2021.

35 Jan Bebbington and Jeffrey Unerman, 'Achieving the United Nations Sustainable Development Goals: An Enabling Role for Accounting Research', Accounting, Auditing \& Accountability Journal 31/1 (2018), 2-24: 3.

36 Frank Biermann, Norichika Kanie and Rakhyun E. Kim, 'Global Governance by Goal-Setting: The Novel Approach of the UN Sustainable Development Goals', Current Opinion in Environmental Sustainability 26 (2017), 26-31: 27.

37 United Nations General Assembly, Habitat III, op. cit. (note 31), 4 .

38 United Nations General Assembly, 'Transforming Our World: The 2030 Agenda for Sustainable Development' (2015), 29, naturalcapital.vn/wp-content/uploads/2017/02/UNDPViet-Nam.pdf, accessed 7 January 2021.

39 United Nations General Assembly, Habitat III, op. cit. (note 31), 4 .

\section{Ibid.}

41 United Nations Environment Programme, SDG 11: Make Cities and Human Settlements Inclusive, Safe, Resilient and Sustainable, unstats.un.org/sdgs/report/2016/goal-11, accessed 7 January 2021.

42 Amy Frearson, 'Skidmore, Owings and Merrill Unveils Vision of New Egyptian Capital for Seven Million People' (2015), dezeen.com/2015/03/20/som-new-capital-city-carioegypt-seven-million-people/, accessed 7 January 2021.

43 Ringelstein, Interview, op. cit. (note 26).

44 Whether a result of deliberate obfuscation or ignorance, the lack of environmental care and consideration in the current plan is evidenced in the rushed construction of the project where "[the Egyptian military] were building streets off the plan that did not line up because of a $50 \mathrm{~m}$ cliff between them'. Ibid.

45 United Nations Biodiversity Conference, 'Biodiversity in Egypt' (2018), cop14-egypt.com/biodiversity/biodiversityin-egypt/2018), accessed 7 January 2021. 
46 Such as the Nubian Ibex, the Egyptian Vulture and the four-toed Jerboa. IUCN, The IUCN Red List of Threatened Species (2019), iucnredlist.org/search/map?query=egypt\&searchType= species, accessed 7 January 2021.

47 Mohamed Hammad, 'Storm Exposes Vulnerabilities of Egypt's New Infrastructure Projects', thearabweekly.com/ storm-exposes-vulnerabilities-egypts-new-infrastructureprojects, accessed 7 January 2021.

48 This calculation is significant only as we have based it on an indicative plan, not construction drawings. Nonetheless, it is revealing of Dar's intentions for greenspace provision.

49 Patrick Werr, 'Aspiring Plans for New Capital City Put Egypt's Resources to the Test' (2017), thenationalnews.com/ business/economy/aspiring-plans-for-new-capital-cityput-egypt-s-resources-to-the-test-1.674116, accessed 7 January 2021

50 Egypt Today, 'Bee'ah Wins Largest Waste Management Contract in Middle East for Egypt's Administrative Capital', egypttoday.com/Article/3/81118/Bee\%E2\%80\%99ah-winslargest-waste-management-contract-in-Middle-East-for, accessed 19 January 2021.

51 Sims, Egypt's Desert Dreams, op. cit. (note 7), 152.

52 Abotera and Ashoub, 'Billboard Space in Egypt', op. cit. (note 25).

53 Mimi Kirk, 'Egypt's Government Wants Out of Its Ancient Capital' (2016), citylab.com/equity/2016/10/egypt-cairocapital-city-move/503924/, accessed 7 January 2021.

54 Karen Piper, 'Revolution of the Thirsty' (2012), placesjournal.org/article/revolution-of-the-thirsty/?cn-reloaded $=1$, accessed 7 January 2021. The main long-term threat to Egypt's continued use of the Nile waters is a recurrence of the drought years of 1980-1987 in the Ethiopian highlands; Sims, Egypt's Desert Dreams, op. cit. (note 7), 67.

55 Abotera and Ashoub, 'Billboard Space in Egypt', op. cit. (note 25).

56 Ayman Hassaan Ahmed Mahmoud and Marwa Adel El-Sayed, 'Development of Sustainable Urban Green Areas in Egyptian New Cities: The Case of El-Sadat City', Landscape and Urban Planning 101/2 (2011): 157-170: 157.

57 John R. Wennersten and Denise Robbins (eds.), Rising Tides: Climate Refugees in the Twenty-first Century (Bloomington, IN: Indiana University Press, 2017), 131.

58 United Nations General Assembly, Habitat III, op. cit. (note 31), 4 .

59 Yahia Shawkat and Mennatu Allah Hendawy, 'Myths and Facts of Urban Planning in Egypt', marsadomran.info/en/ policy_analysis/2016/11/501/, accessed 7 January 2021.

60 Sims, Egypt's Desert Dreams, op. cit. (note 7), xxxiii.

61 Edge Holding, Development Brochure, 17, headway-egypt. com/wp-content/uploads/2018/07/1531137905423_OIA-Brochure.pdf, accessed 7 January 2021.

62 Mona Abaza, 'Critical Commentary: Cairo's Downtown Imagined: Dubaisation or Nostalgia?', Urban Studies 48/6 (2011), 1075-1087: 1075.

63 Cube Consultants, 'The New Administrative Capital in Egypt', cubeconsultants.org/thecapitalcairo/, accessed 7 January 2021.

64 Sims, Egypt's Desert Dreams, op. cit. (note 7), xxvii-xxviii.
65 Ibid., xxviii.

66 Pettit, 'Hopeful City', op. cit. (note 5), 1058

67 Eric Denis, 'Cairo as Neoliberal Capital?', in: Diane Singerman, Paul Amar and Paul Edouard Amar (eds.), Cairo Cosmopolitan: Politics, Culture, and Urban Space in the New Globalized Middle East (Cairo: American University in Cairo Press, 2006), 5.

68 Ibid., 30.

69 Linda Herrera, 'The Precarity of Youth: Entrepreneurship Is Not the Solution', madamasr.com/en/2017/02/11/ opinion/u/the-precarity-of-youth-entrepreneurship-isnot-the-solution/, accessed 7 January 2021.

70 Petra Kuppinger, 'Exclusive Greenery: New Gated Communities in Cairo', City \& Society 16/2 (2004), 35-61: 42.

71 Vivian Yee, 'Egypt Approves New Muscle for el-Sisi, Its Strongman Leader', nytimes.com/2019/04/23/world/middleeast/sisi-egypt-referendum.html, accessed 7 January 2021.

72 Peter Hessler, 'Egypt's Failed Revolution', newyorker.com/ magazine/2017/01/02/egypts-failed-revolution, accessed 7 January 2021

73 Eric Denis, 'Urban Planning and Growth in Cairo', Middle East Report 27 (1997), 7-12: 9

74 Adhaf Soueif, Cairo: My City, Our Revolution (London: Bloomsbury Publishing, 2012), 11.

75 From an interview with Nezar Alsayyad, Cairo-born professor of Architecture, Planning and Urban History and Chair of the Center for Middle Eastern Studies at the University of California at Berkeley. Aaron Britt, Design and History of Tahrir Square (2011), dwell.com/collection/design-and-history-oftahrir-square-1526b353, accessed 19 January 2021.

76 This has historical precedent, however: 'Throughout the centuries, rulers of Egypt have been estranged from Egyptians, shielded in their fortresses from the people and invaders alike,' says Assem al-Dessouky, professor of Modern History at Cairo University. The ACC marks a return to this model of social division in contrast with Ismail's 1860 development of downtown Cairo that was inspired by French urban planning's desire to engage the expanding middle class in the political process. Ahmed Abdel Hafez, 'A History of Urban Development from Pharaonic to the Future', egyptindependent.com/history-urban-development-pharaonic-future/, accessed 7 January 2021.

77 Sims, Egypt's Desert Dreams, op. cit. (note 7), xxvii-xxviii.

78 The legal framework mirrors this. In 2013, the government passed a law that effectively forbids any demonstration without official approval, with a maximum punishment of a year in prison. Hessler, 'Egypt's Failed Revolution', op. cit. (note 72).

79 Gehan Selim, 'Between Order and Modernity: Resurgence Planning in Revolutionary Egypt', Journal of Urban History 42/1 (2016): 180-200:182

80 Christine Ellem, 'No Little Plans: Canberra, via Chicago, Washington DC, The Philippines, and onwards', Thesis Eleven 123/1 (2014), 106-122:107.

81 Not only this, but the architectural styles of the proposed government buildings borrow heavily from Greek Classicism and French Rococo styles, which are used to represent power, opulence and high culture. Denis, 'Urban Planning and Growth in Cairo', op. cit (note 73), 9-10.
82 Pernilla Ouis, 'Greening the Emirates: The Modern Construction of Nature in the United Arab Emirates', Cultural Geographies 9 (2002), 334-347: 339.

83 John Brookes, Gardens of Paradise: The History and Design of the Great Islamic Gardens (London: Weidenfeld and Nicolson, 1987), 24

84 Similar dynamics can be observed in Dubai. Julian Bolleter, Desert Paradises: Surveying the Landscapes of Dubai's Urban Model (London: Routledge, 2019).

85 Kim Dovey, Urban Design Thinking: A Conceptual Toolkit (London: Bloomsbury, 2016), 125.

86 This mirrors the situation in Dubai. See Julian Bolleter, 'Para-Scape: Landscape Architecture in Dubai', Journal of Landscape Architecture 9/4 (2009), 28-55.

87 Mohamed M. Abdelaziz Farid and Alaa Mohamed Samy Ahmed, 'Urban Identity and Lifestyles of Gated Communities in Egypt', Cities' Identity Through Architecture and Arts: Proceedings of the International Conference on Cities' Identity through Architecture and Arts (CITAA 2017) (Cairo: Routledge, 2018), 337.

88 United Nations General Assembly, Habitat III, op. cit. (note 31), 4 .

\section{BIOGRAPHICAL NOTES}

Julian Bolleter is the co-director of the Australian Urban Design Research Centre (AUDRC) at the University of Western Australia and is the programme director of AUDRC's Master of Urban Design course. His role at the AUDRC also includes conducting research projects for the Australian Research Council and Western Australian state government. Bolleter is an experienced urban designer and has practised in Australia, the USA, the UK and the Middle East.

Robert Cameron is an associate lecturer and researcher at the Australian Urban Design Research Centre (AUDRC) and the University of Western Australia's School of Design. His research explores emerging technologies through interdisciplinary design practice to better understand their impact on the perception and production of cities. Cameron's interest in technology and cities has drawn him to work at a range of different scales and on a range of media, having worked as an architect at ARM Architecture, as an animator/graphic designer and a public artist.

\section{CONTACT}

\section{Julian Bolleter}

University of Western Australia

Level 2, 1002 Hay Street

Perth, WA, 6000

Australia

Phone: (08) 63186200

julian.bolleter@uwa.edu.au

Robert Cameron

University of Western Australia

Level 2, 1002 Hay Street

Perth, WA, 6000

Australia

Phone: (08) 63186200

robert.cameron@uwa.edu.au 